Ikke akupunktur under fødselen

$45 \%$ av danske primipara med normal graviditet får ristimulering som følge av inerti. Nå har man undersøkt om akupunktur kan være et virksomt alternativ som ristimulerende behandling (Ugeskr Læger 2010; 172: 289-93). Det primære effektmål var progresjon i cervixdilatasjonen over to timer.

84 kvinner ble randomisert til akupunktur eller placebo. Kontrollgruppen fikk ingen behandling. Resultatene viste ingen signifikant effekt av akupunktur på fødselens progresjon og på fødselsvarigheten, men forfatterne påpeker at resultatene må tas med et forbehold, ettersom studien var for liten i henhold til styrkeberegning.

\title{
Også pipe- og sigarrøyking er helseskadelig
}

\section{De som røyker pipe eller sigar, men ikke sigaretter, har oftere luftveis- obstruksjon enn de som aldri røyker.}

Pipe- og sigarrøyking er blitt mer populært $\mathrm{i}$ USA de siste årene. Mange synes å tro at dette er mindre helseskadelig enn sigarettrøyking, som er den viktigste årsaken til kronisk obstruktiv lungesykdom (kols). Det foreligger få studier om lungefunksjon ved pipe- og sigarrøyking.

I en populasjonsbasert studie med 3528 personer hadde de som røykte pipe eller sigarer, men ikke sigaretter, oftere tegn til luftveisobstruksjon ved spirometri enn de som aldri hadde røykt (OR 2,31; $95 \% \mathrm{KI}$ 1,04-5,11) (1). Hos dem som også hadde røykt sigaretter, var risikoen for luftveisobstruksjon enda høyere (OR 3,43; KI 1,75-6,71). Reduksjonen i lungefunksjon tiltok med antall år med pipe- eller sigarrøy- king. Pipe- og sigarrøykere hadde høyere kotininnivåer i urinen enn aldrirøykerne.

- Denne studien bekrefter at også røyking av pipe og sigarer er helsefarlig, sier forskningsleder Karl Erik Lund ved Statens institutt for rusmiddelforskning (SIRUS).

- I Norge har pipetobakk og sigarer en samlet markedsandel på kun $1 \%$, og forbruket av disse produktene har ikke vist samme økning som i USA. Likevel er det viktig for leger å informere pasientene om de negative helseeffekter av pipe- og sigarrøyking, sier han.

\section{Petter Gjersvik \\ petjense@online.no \\ Tidsskriftet}

\section{Litteratur}

1. Rodriguez J, Jiang R, Johnson WC et al. The association of pipe and cigar use with cotinine levels, lung function, and airflow obstruction. A crosssectional study. Ann Intern Med 2010; 152: 201-10.

\section{Nye vekstkurver for danske barn}

Barn i Danmark er høyere, tyngre og har høyere kroppsmasseindeks enn angitt i tidligere vekstkurver og WHO-standarden. Det viser en ny studie (Acta Paediatr 2010; 99: 268-78).

Hittil har tilgjengelige vekstkurver vært basert på danske målinger fra 1976-77 eller på målinger av barn fra mange land sammenfattet i WHOs globale vekststandard. Forfatterne av den nye studien har laget nye danske standarder og sammenliknet disse med de andre.

Gjennomsnittlig lengde, høyde og kroppsmasseindeks ved fødselen og i de første levemånedene var signifikant økt i forhold til de gamle vekstkurvene, men deretter ble forskjellene mindre og ved ett års alder var $\mathrm{BMI}$ redusert. Forfatterne mener at de nye kurvene representerer et sunnere vekstmønster i første leveår enn de gamle vekstkurvene, men kanskje er vekstmønsteret i WHO-standarden - hvor barna blir ammet lenger og vokser litt langsommere - enda sunnere, ifølge en kommentar i Ugeskrift for Læger (2010; 171: 767).

\section{Lovende resultater med navlestrengsstamceller}

For første gang beskrives ex vivo-ekspansjon av antall funksjonelle hematopoetiske stamceller fra navlestreng.

Forsinket hematologisk rekonstitusjon etter navlestrengstransplantasjon skyldes trolig lavt antall stamceller. Selv bruk av celler fra to navlestrenger gir forsinket rekonstitusjon hos voksne. Metoder for ex vivo-ekspansjon av funksjonelle hematopoetiske stamceller fra navlestreng er derfor av interesse.

I en ny studie beskrives en metode for å øke mengden av CD34-positive navlestrengsceller ex vivo mer enn 100 ganger (1). Etter at de ekspanderte cellene viste rask og solid rekonstitusjon av immunde- fekte mus, ble en klinisk fase 1-studie igangsatt. Pasientene hadde akutt leukemi i morfologisk remisjon. Etter myeloablasjon ble de transplantert med ekspanderte CD34-positive celler pluss celler fra en umanipulert navlestreng.

Så langt er ti pasienter inkludert (median alder 27,5 år). Disse fikk i gjennomsnitt $6 \cdot 10^{6}$ ekspanderte CD34-positive celler $/ \mathrm{kg}$ og 0,24 $\cdot 10^{6} \mathrm{CD} 34$-positive celler fra umanipulert navlestreng $(p=0,0004)$. Infusjon av manipulerte celler ga ikke uønskede reaksjoner. En pasient viste primær transplantatrejeksjon. I de andre ni var median tid til $>500$ nøytrofile granulocytter/ $\mu 1$ 16 dager, mens den var 26 dager i en gruppe pasienter som fikk stamceller fra to navlestrenger $(\mathrm{p}=0,002)$. Gjennomsnittlig oppfølgingstid var 354 dager - da var sju av de ti i live uten leukemiresidiv og med komplett rekonstitusjon av hematopoesen ved transplantatene. Etter ett år bidro utelukkende ikke-ekspanderte stamceller til hematopoesen. Det kan skyldes at de ekspanderte ikke inneholdt modne T-celler.

\section{Bjarte G. Solheim}

bjagees@online.no

Immunologisk avdeling

Oslo universitetssykehus, Rikshospitalet

\section{Litteratur}

. Delaney C, Heimfeld S, Brashem-Stein C et al. Notch-mediated expansion of human cord blood progenitor cells capable of rapid myeloid reconstitution. Nat Med 2010; 16: 232-6. 